\title{
Embryonic stem cells in scaffold-free three- dimensional cell culture: osteogenic differentiation and bone generation
}

\author{
Jörg Handschel', Christian Naujoks*, Rita Depprich', Lydia Lammers², Norbert Kübler', Ulrich Meyer ${ }^{1}$ and
} Hans-Peter Wiesmann ${ }^{3}$

\begin{abstract}
Extracorporeal formation of mineralized bone-like tissue is still an unsolved challenge in tissue engineering. Embryonic stem cells may open up new therapeutic options for the future and should be an interesting model for the analysis of fetal organogenesis. Here we describe a technique for culturing embryonic stem cells (ESCS) in the absence of artificial scaffolds which generated mineralized miromasses. Embryonic stem cells were harvested and osteogenic differentiation was stimulated by the addition of dexamethasone, ascorbic acid, and Bglycerolphosphate (DAG). After three days of cultivation microspheres were formed. These spherical threedimensional cell units showed a peripheral zone consisting of densely packed cell layers surrounded by minerals that were embedded in the extracellular matrix. Alizarine red staining confirmed evidence of mineralization after 10 days of DAG stimulation in the stimulated but not in the control group. Transmission electron microscopy demonstrated scorching crystallites and collagenous fibrils as early indication of bone formation. These extracellular structures resembled hydroxyl apatite-like crystals as demonstrated by distinct diffraction patterns using electron diffraction analysis. The micromass culture technique is an appropriate model to form three-dimensional bone-like micro-units without the need for an underlying scaffold. Further studies will have to show whether the technique is applicable also to pluripotent stem cells of different origin.
\end{abstract}

Keywords: Embryonal stem cell, osteogenic tissue engineering, three-dimensional culture technique, scaffold free tissue, hydroxyl apatite

\section{Introduction}

Bony defects have various causes and often turn out to be a major therapeutic challenge. Until today, the reconstruction of bone using autologous grafts has been recognized as the gold standard because it provides biological active cells with osteoinductive properties and avoids any immunological reactions [1]. Unfortunately, the harvesting of these grafts causes donor-side defects and shows a quantitative limitation [2-4]. Artificial materials and extracorporeal tissue formation are alternative approaches for the reconstruction of bone defects, because they neither cause donor-site lesions nor is their availabilty restricted.

\footnotetext{
* Correspondence: christian.naujoks@med.uni-duesseldorf.de 'Department for Cranio- and Maxillofacial Surgery, Heinrich-Heine-Universität, Moorenstr. 5, D- 40225 Düsseldorf, Germany

Full list of author information is available at the end of the article
}

Bone is a highly specialized tissue of the organism which is generated by mineralization of the extracellular matrix called osteoid. Osteoblasts and osteoclasts contribute to the formation and remodelling of bone tissue. However, there are further cell types e.g. endothelia cells, which are also essential for bone formation [5]. The complex cell-driven process of bone formation starts early in the embryo and results in bone tissue with unique features that combines stiffness and elasticity with the ability to regenerate itself [6]. A key feature of bone tissue is the presence of biological active apatite crystals. These crystals were formatted by the mineralization of the extracellular matrix (osteoid) with calcium and phosphate ions. The process of mineralization can be monitored histologically by special stainings like alizarin red or ultrastructurally by transmission (TEM) and scanning electron microscopy (SEM). 
Common approaches for engineering bone ex vivo are usually based on a combination of cells and scaffolds [7-9]. Even the ex vivo de novo bone building starts with the secretion of collagen via matrix vesicles followed by the mineralisation of the extracellular matrix molecules [7]. It has been reported that cells in threedimensional cultures exert higher proliferation rates than cells cultured in monolayers, suggesting that their differentiation resembles more closely that seen in situ [10-12]. Furthermore, it is assumed that cells are more flexible to change their shape and behaviour upon specific cell signals when they are cultured in three-dimensional as compared to two-dimensional cultures [13,14].

Whereas a multitude of extracorporeal bone tissue engineering approaches have been undertaken to fabricate bone tissue ex vivo, up to now cell culture-based methods for synthesizing bone-like tissue on a structural level are still limited due to technical restrictions [15]. Here we describe that mineralized bone-like matrix is produced by osteoinduced totipotent embryonic stem cells cultured in three-dimensional micromass technique in the absence of any scaffold. The osteogenic differentiation of the cells was induced by the addition of dexamethasone, ascorbic acid, and $ß$-glycerolphosphate (DAG) to the medium $[16,17]$. The features of ossification mimic in-vivo bone formation, thus enabling matured mineralized bone matrix to be generated.

\section{Materials and methods \\ Cell culture}

A cell culture method for producing mineralized biomaterial-free, three-dimensional cell units up to $0.4 \mathrm{~mm}$ in diameter was established. Feeder-independent murine embryonic stem cells (ESCs) were kindly provided by $\mathrm{K}$. Pfeffer (Institute for Microbiology, Heinrich Heine University of Düsseldorf, Germany). The cells were derived from the inner cell mass of blastocysts extracted from C57BL/6 mice and tested positive for the stem cell markers Pouf1 (alias Oct4) and Foxd3 [18]. Cells were cultured in Dulbecco's modified Eagle medium (DMEM, Gibco) supplemented with penicillin (100 U/ml, Grünenthal), streptomycin (100 U/ml, Hefa-pharma), 2-mercaptoethanol (500 mM, Gibco), ultraglutamine (2 mM; Cambrex), leukemia inhibitor factor $(1000 \mathrm{U} / \mathrm{ml}$; Chemicon) and $15 \%$ fetal calf serum. The cells were split every second day and the medium was changed every day by detaching the cells with $0.25 \%$ trypsin (Pan Biotech). ESCs were detached from the plate, centrifuged and resuspended in normal growth medium $(1 \times 106$ cells/ $\mathrm{ml})$.

To prevent adherence of the cells leading to the formation of monolayers, the microsphere assembly bioreactor was prepared by filling $60 \mu \mathrm{l}$ of a solution consisting of $2 \%$ agarose in DMEM (without any supplements) into 96-well plates. After curing of the agarose solution to each well, $180 \mu \mathrm{l}$ of cell suspension was added and the cells were incubated overnight. The old medium was replaced by equal volumes $(160 \mu \mathrm{l})$ of control medium and control medium containing 100 $\mathrm{nM}$ dexamethasone, $50 \mu \mathrm{M}$ ascorbic acid, and $10 \mathrm{mM}$ $\beta$-glyerolphosphate (all from Sigma), respectivey. Thus, half of the culture chambers were incubated in the presence of dexamethasone, ascorbic acid, and DAG, (DAG $(+))$ to induce the osteogenic differentiation, while the other half used as a control was cultivated in medium without these stimuli (DAG (-)). Both cell populations were kept in culture for three weeks in an incubator under a humified atmosphere $\left(37^{\circ} \mathrm{C}, 90 \%\right.$ humidity, $5 \%$ $\mathrm{CO}_{2}$ ). The medium was changed every day. After 3, 7, 10 , and 21 days one quarter of the cultivated wells with microspheres of the + and - DAG group was harvested and transferred into Petri dishes for a washing step with phosphate-buffered saline (PBS). Subsequently the preparation of the spheres for the different analysis was performed.

\section{Histological analysis}

For histologiacal analysis, micromasses were fixed in formalin (4\%) until further procession. Formaline-fixed microspheres were dehydrated in increasing ethanol concentrations (50\%, 75\%, 90\% and 100\%) and embedded in paraffin (Paraplast plus). Sections $(4 \mu \mathrm{m})$ were mounted on Superfrost slides, deparaffinized with xylol and rehydrated in decreasing ethanol concentrations. Samples were stained with alizarine red solution (2\%) to detect calcium and counterstained with toluidine blue, as mentioned in the literature. Briefly, after staining with toludine blue the slides were counterstained with alizarin red (mixture of $0.5 \mathrm{~g}$ alizarin red and 0.5 $\mathrm{ml} 0.28 \%$ NH3 with $45 \mathrm{ml}$ distilled water ( $\mathrm{pH}$ : 6.4)). Before the slides were finally covered with entellan, they were incubated in xylene. A descriptive analysis was performed.

\section{Scanning electron microscopy}

For scanning electron microscopy, micromasses were fixed in glutaraldehyde (4\%) followed by a washing step with $0.1 \mathrm{M}$ PBS. Microspheres were dehydrated in increasing isopropanol concentrations (30\%, 50\%, 70\%, $90 \%$, 96\%, and 100\%; 30 minutes for each concentration). The critical pont drying was performed following the instructors protocol. In this procedure isopropanol was substituted for $\mathrm{CO} 2$ by five washing steps. After drying, the specimens were directly put on a carbon pad of a SEM-holder (Cambridge). For morphological studies, probes were sputtered with platinum, whereas for EDX analysis, samples were coated with carbon using standard techniques. Scanning electron microscopy was 
performed with a DSM 960 (Zeiss) microscope using an acceleration voltage of $5-15 \mathrm{kV}$.

\section{Transmission electron microscopy}

For TEM, specimens were fixated in glutaraldehyde (2.5\%) and embedded in araldite. For morphological analysis, a fixation with osmium tetroxide and glutaraldehyde was carried out. Specimens were washed three times with 0.1 M PBS for 10 minutes each. Microspheres were dehydrated in increasing isopropanol concentrations $(50 \%, 70 \%, 90 \%, 96 \%$ and $100 \%$; 30 minutes for each concentration) and followed by a transfer into propylene oxid. Afterwards the spheres were transferred to pure araldite by using intermediate ratios of mixtures (100\% propylene oxide, $2 / 1$ propylene oxide/araldite, $1 /$ $1,1 / 2,100 \%$ araldite). To harden the araldite the specimen were kept at $42^{\circ} \mathrm{C}$ for 24 hours and afterwards were sectioned with a microtome (Ultracut $\mathrm{S}$, Reichert). For morphological studies ultrathin sections were stained with osmium tetroxide $\left(\mathrm{OsO}_{4}\right)$. For ultrastructural assessment of the mineral substance no staining was performed and the water contact during preparation, particulary during sectioning, was reduced to a minimum in order to avoid dissolution or redistribution. The ultrathin slides were applied to copper grids and contrasted with uranyl acetate. Analyses were performed with an acceleration voltage of $80 \mathrm{kV}$ with EM902 (Zeiss). Electron spectroscopic diffraction analysis was performed with the specimens used for the TEM. Contact time of the slides with water on the microtome was limited to a few seconds to avoid redistribution of the crystallites. Analyses were performed with an EM902 (Zeiss) microscopy using $80 \mathrm{kV}$ acceleration voltage and a camera length of $650 \mathrm{~mm}$. D-values for the 002 diffraction patterns were calculated according to Arnold et al. and Plate et al. $[19,20]$.

\section{Results}

After three days all cell cultures formed spheroid, threedimensional cell units in high density $\left(5 \times 10^{6}\right.$ cells $\left./ \mathrm{ml}\right)$, which appeared as oval micromasses. At that time, neither in specimens from the DAGstimulated group nor in the non-stimulated group signs of mineralization were detectable. After 10 days of cultivation the first indications of mineralization were visible in the DAGtreated cells, while they were absent in non-stimulated cells. Mineralization proceeded in the centre of the stimulated specimens and became more clearly visible after 3 weeks of cultivation in the presence of osteoinductive stimuli. Numerous living cells were detected in the mineralized centre of the spheres by means of toluidine blue staining (Figure 1). Generally, the mineralization was most prominent in the centre of the sphere, as demonstrated in histological sections stained with

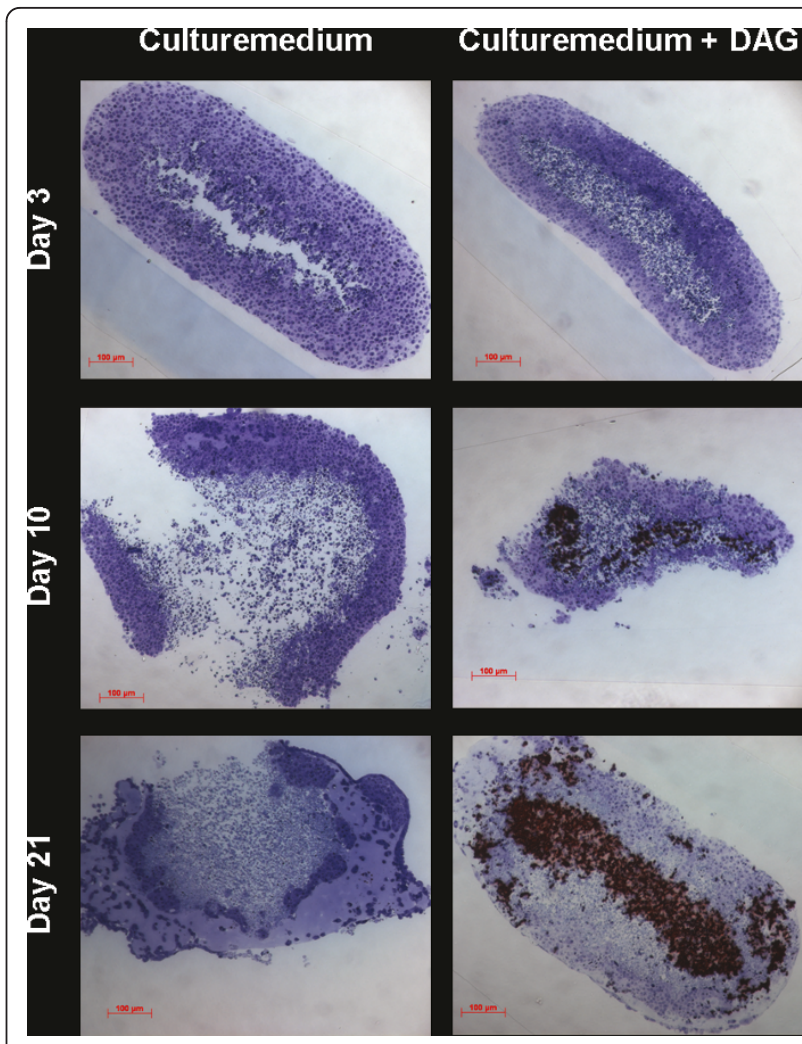

Figure 1 Micromasses consisting of embryonic stem cells were cultured with or without DAG and stained with toluidine blue followed by counterstaining with alizarin red. Shown is evidence for the mineralization in the centre of the micromasses, which were stained in red.

alizarin red (Figure 1). The SEM analysis confirmed the differences regarding the distribution pattern of the formed mineral and the quantitative differences. The + DAG group showed an intense mineralization in the centre of the spheres (Figure 2). Transmission electron

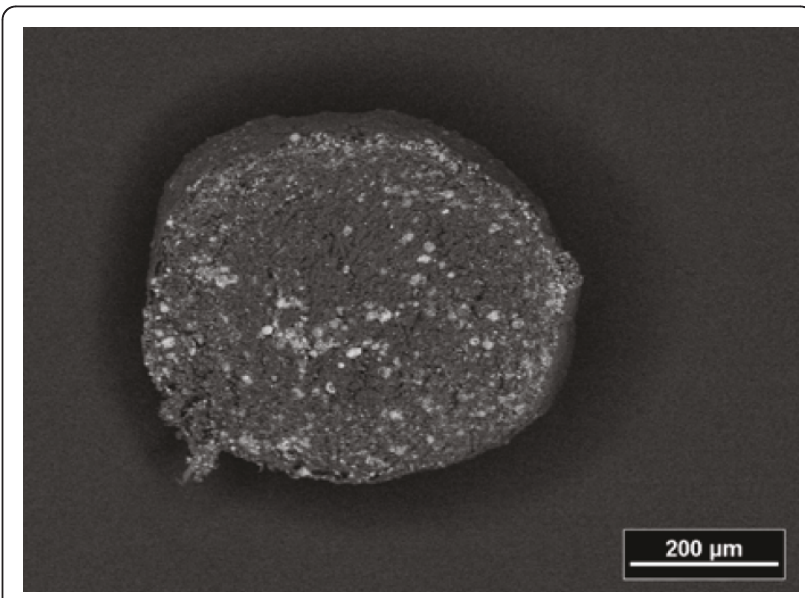

Figure 2 SEM image of the mineralization in the centre of a +DAG spheres after 21 days 
microscopy (TEM) confirmed the presence of scorching crystallites in the mineralized area, which appeared after 21 days of cultivation (Figure 3a). Theses crystals were typically embedded in an extracellular matrix containing numerous collagenous fibrils (Figure 3b). The spherical cell units had a peripheral zone consisting of densely packed cell layers, which surrounded the minerals. To demonstrate that the mineralized matrix in the DAGtreated group is composed of hydroxyl apatite crystals, electron spectroscopic diffraction analysis was performed (Figure 4). In accordance with Arnold et al. and Plate et al., the $\mathrm{d}$-value for the diffraction ring 002 was calculated $(0.344 \mathrm{~nm})$ (Figure 3 and 4$)$.

\section{Discussion}

The de-novo formation of bone in terms of tissue engineering requires cells, matrix and growth factors. For creating larger tissue constructs for surgical use, natural or artificial biomaterials are additionally needed as scaffolds. However, there is controversy about the use of biomaterials as a scaffold because the physicochemical properties of the biomaterials influence the proliferation and gene expression of the cells $[9,21,22]$. Even protein coating of the scaffold has impact on the attachment of the cells [23-25]. It is generally accepted that no existing artificial or natural scaffold can meet all the requirements for ruling out undesired effects. The micromass culture technique may be an alternative for substituting artificial scaffolds. In contrast to monolayers, cell culture-based techniques in three-dimensional space appear to more closely resemble in-vivo conditions [11]. It is well known that many functions of the cells, e.g. differentiation and proliferation, rely on intact cell-cell interactions and a tight attachment to extracellular matrix components. In micromasses, the cells can interact with

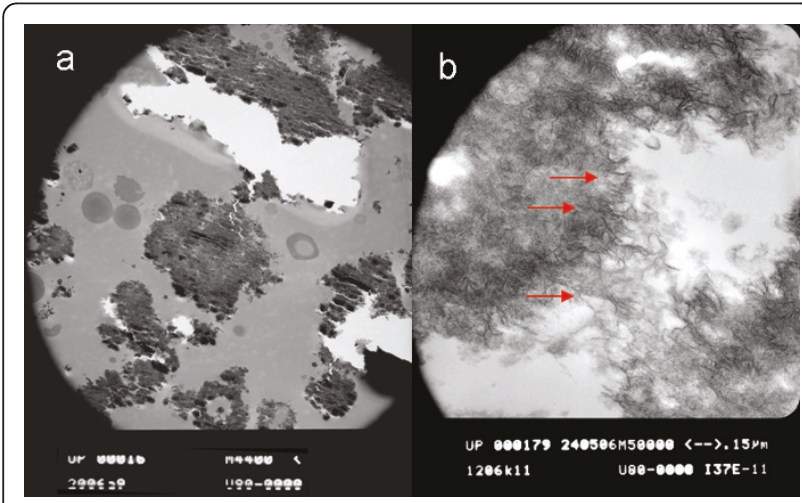

Figure 3 ESC micromass cultured for 21 days in the presence of medium containing dexamethasone, ascorbic acid, and Bglycerolphosphate (DAG). Transmission electron microscopy demonstrated scorching crystallites (a) and collagen fibrils (b) in the mineralized area.

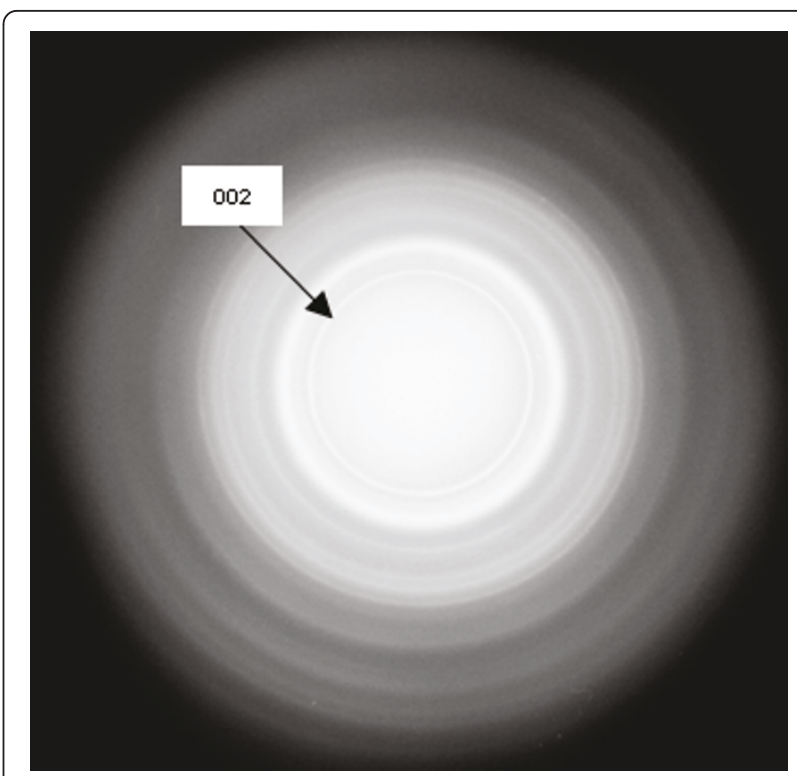

Figure 4 Electron spectroscopic diffraction in the centre of DAG-treated ESC microspheres showed typical patterns for hydroxyl apatite formation (day 21).

each other and maintain these interactions [26]. Former studies have shown that in micromass culture techniques a cartilaginous differentiation of ESCs is feasible $[27,28]$. In the presented study we show that stimulated ESCs cultured in micromass technique form minealized microspheres during cultivation.

Aggregation of cells is the pivotal stage in the development of skeletal tissues and the primary resource from which the skeleton is built and through which the skeleton is modified ontogenetically [29]. Mineralized bony units formed ex vivo seem to be an ideal biomaterial because they combine the structural features of bone. Currently, the best treatment option for bone defects utilises the enhanced regeneration potential of embryonic stem cells [30]. In this respect, fusion of multiple bony units may allow the reconstruction of larger skeletal elements. Through the ability of embryonic stem cells to differentiate along the whole osteogenic pathway, embryonic stem cell transplantation may play a future role in the treatment of generalized bone diseases. Furthermore, we show that osteoinductive stimuli including DAG support the mineralization of the extracellular matrix and that stimulated micromasses produce more mineralized extracellular matrix than micromasses cultured in the absence of these stimuli. To verify that the matrix consists of hydroxyl apatite, we performed transmission electron microscopy and revealed a timedependent occurrence of scorching crystallites in the interior of the microspheres. Using electron spectroscopic diffraction we confirmed that the crystallites consisted of hydroxyl apatite. Furthermore, we detected 
collagen fibrils that were morphologically very similar to collagenous fibrils within bone tissue. Collagen I fibrils are known to be a major extracellular matrix component of bone tissue [5,31]. Plate and co-workers described the formation of hydroxyl apatite in bone and dentin as a multistage process resulting in the deposition of a mineralized matrix. These calcium-phosphate crystals coordinate longitudinally and accumulate as scorching crystallites [20]. In samples from stimulated ESCs we detected crystal-like structures in the interior of the microspheres. These ESC microspheres resemble aggregates consisting of preosteoblasts.

Our finding of a mineralization in microspheres of DAG-treated ESCs seems to share similarity to the formation of bone and dentin in vivo. Thus, it appears that osteologous differentiation of ESC micromasses may be a feasible approach to advance the bony reconstruction of large defects. However, the size of the microspheres is limited possibly due to restricted diffusion of nutrients and we are currently unable to format larger tissue constructs without support by artificial matrices. The use of bioreactors may be an adequate technique to gain larger tissue constructs without the need for a scaffold by simply transferring osteologously differentiated ECS micromasses [32].

Nevertheless, the micromass culture technique may be an appropriate model to analyse the formation of the skeleton during embryonic or fetal organogenesis. Aggregation of cells to a critical size is a fundamental step in initiating organogenesis of vertebrates [33]. Hall and Miyake assume that the condensation of cells is a precondition for skeleton formation that promotes the differentiation of cells to osteoblasts and chondroblasts $[29,34]$. Furthermore, the three-dimensional micromass culture technique may be a useful method for identifying substances that enhance mineralization.

The use of embryonic stem cells will probably play a major role in tissue engineering in the future because of the remakable potential and differentiation capacity of ESCs. Prior to clinical application, many challenges need to be faced in future studies, particularly with respect to immune tolerance and the formation of malignant tumors in the host organism. However, the studies by Burt and coworkers are promising with regard to immuntolerance. They grafted ESCs into MHC-mismatched mice and found no clinical or histological evidence for a graft-versus-host or host-versus-graft reaction [35].

Furthermore, Zavazava has demonstrated that ESCs have the potential to induce immune tolerance [36] and revealed evidence for a suppression of the MHC gene expression [37]. Trounson and colleagues showed that transplanted undifferentiated ESCs may induce teratoma and teratocarcinoma [38]. Even if many other authors could not find any indication of malignant transformation in their studies [39], the eventuality of cancer induction is still an argument for the restricted use of these cells. Lastly, there are legal and ethical restrictions for the use of human ESCs.

Despite the above mentioned doubts about the use of ESCs, they may open up new therapeutic options for future application and may turn out to be interesting models for the study of fetal organogenesis. Furthermore, the results may be transferred to other pluripotent stem cells, such as umbilical somatic stem cells, which have not so many restrictions.

\section{Author details}

${ }^{1}$ Department for Cranio- and Maxillofacial Surgery, Heinrich-Heine-Universität, Moorenstr. 5, D- 40225 Düsseldorf, Germany. ${ }^{2}$ Department for Cranio- and Maxillofacial Surgery, Westfälische-Wilhelms-Universität, Waldeyerstr. 30, D48149 Münster, Germany. ${ }^{3}$ Department for Material Science, Technical University of Dresden, Helmholtzstr. 7, D-01062 Dresden, Germany.

\section{Authors' contributions}

All authors have read and approved the final manuscript.

\section{Competing interests}

The authors declare that they have no competing interests.

Received: 10 February 2011 Accepted: 14 July 2011

Published: 14 July 2011

\section{References}

1. Pretorius JA, Melsen B, Nel JC, Germishuys PJ: A histomorphometric evaluation of factors influencing the healing of bony defects surrounding implants. Int J Oral Maxillofac Implants 2005, 20:387-398.

2. Nkenke E, Schultze-Mosgau S, Radespiel-Troger M, Kloss F, Neukam FW: Morbidity of harvesting of chin grafts: a prospective study. Clin Oral Implants Res 2001, 12:495-502.

3. Nkenke E, Weisbach V, Winckler E, Kessler P, Schultze-Mosgau S, Wiltfang J, Neukam FW: Morbidity of harvesting of bone grafts from the iliac crest for preprosthetic augmentation procedures: a prospective study. Int J Oral Maxillofac Surg 2004, 33:157-163.

4. Sasso RC, LeHuec JC, Shaffrey C: lliac crest bone graft donor site pain after anterior lumbar interbody fusion: a prospective patient satisfaction outcome assessment. J Spinal Disord Tech 2005, 18(Suppl):S77-81.

5. Löffler G: Basiswissen Biochemie. 4 Auflage edition. Berlin, Heidelberg, New York: Springer Verlag; 2000.

6. Weiner S, Traub W, Wagner HD: Lamellar bone: structure-function relations. J Struct Biol 1999, 126:241-255.

7. Boskey AL: Musculoskeletal disorders and orthopedic conditions. Jama 2001, 285:619-623.

8. Meyer U, Wiesmann HP: Bone and cartilage tissue engineering Heidelberg, Berlin, Tokyo, New York: Springer; 2005.

9. Handschel J, Berr K, Depprich R, Naujoks C, Kubler NR, Meyer U, Ommerborn M, Lammers L: Compatibility of Embryonic Stem Cells with Biomaterials. J Biomater Appl 2008.

10. Abbott A: Cell culture: biology's new dimension. Nature 2003, 424:870-872.

11. Handschel JG, Depprich RA, Kubler NR, Wiesmann HP, Ommerborn M, Meyer U: Prospects of micromass culture technology in tissue engineering. Head Face Med 2007, 3:4.

12. Cukierman E, Pankov R, Stevens DR, Yamada KM: Taking cell-matrix adhesions to the third dimension. Science 2001, 294:1708-1712.

13. Weaver VM, Petersen OW, Wang F, Larabell CA, Briand P, Damsky C, Bissell MJ: Reversion of the malignant phenotype of human breast cells in three-dimensional culture and in vivo by integrin blocking antibodies. J Cell Biol 1997, 137:231-245. 
14. Sivaraman A, Leach JK, Townsend S, lida T, Hogan BJ, Stolz DB, Fry R, Samson LD, Tannenbaum SR, Griffith LG: A microscale in vitro physiological model of the liver: predictive screens for drug metabolism and enzyme induction. Curr Drug Metab 2005, 6:569-591.

15. Green D, Walsh D, Mann S, Oreffo RO: The potential of biomimesis in bone tissue engineering: lessons from the design and synthesis of invertebrate skeletons. Bone 2002, 30:810-815.

16. Bielby RC, Boccaccini AR, Polak JM, Buttery LD: In vitro differentiation and in vivo mineralization of osteogenic cells derived from human embryonic stem cells. Tissue Eng 2004, 10:1518-1525.

17. Chaudhry GR, Yao D, Smith A, Hussain A: Osteogenic Cells Derived From Embryonic Stem Cells Produced Bone Nodules in Three-Dimensional Scaffolds. J Biomed Biotechnol 2004, 2004:203-210.

18. Baharvand H, Ashtiani SK, Taee A, Massumi M, Valojerdi MR, Yazdi PE, Moradi SZ, Farrokhi A: Generation of new human embryonic stem cell lines with diploid and triploid karyotypes. Dev Growth Differ 2006, 48:117-128.

19. Arnold S, Plate U, Wiesmann HP, Stratmann U, Kohl H, Hohling HJ: Quantitative electron spectroscopic diffraction analyses of the crystal formation in dentine. J Microsc 1999, 195(Pt 1):58-63.

20. Plate U, Arnold S, Stratmann U, Wiesmann HP, Hohling HJ: General principle of ordered apatitic crystal formation in enamel and collagen rich hard tissues. Connect Tissue Res 1998, 38:149-157, discussion 201-145.

21. Meyer U, Joos U, Wiesmann HP: Biological and biophysical principles in extracorporal bone tissue engineering. Part I. Int I Oral Maxillofac Surg 2004, 33:325-332.

22. Kasaj A, Reichert C, Gotz H, Rohrig B, Smeets R, Willershausen B: In vitro evaluation of various bioabsorbable and nonresorbable barrier membranes for guided tissue regeneration. Head Face Med 2008, 4:22.

23. Dennis JE, Haynesworth SE, Young RG, Caplan Al: Osteogenesis in marrowderived mesenchymal cell porous ceramic composites transplanted subcutaneously: effect of fibronectin and laminin on cell retention and rate of osteogenic expression. Cell Transplant 1992, 1:23-32.

24. Meyer U, Meyer T, Jones DB: Attachment kinetics, proliferation rates and vinculin assembly of bovine osteoblasts cultured on different pre-coated artificial substrates. J Mater Sci Mater Med 1998, 9:301-307.

25. Petrovic L, Schlegel AK, Schultze-Mosgau S, Wiltfang J: Different substitute biomaterials as potential scaffolds in tissue engineering. Int J Oral Maxillofac Implants 2006, 21:225-231.

26. Boudreau NJ, Jones PL: Extracellular matrix and integrin signalling: the shape of things to come. Biochem J 1999, 339(Pt 3):481-488.

27. Naito J, Kaji H, Sowa H, Hendy GN, Sugimoto T, Chihara K: Menin suppresses osteoblast differentiation by antagonizing the AP-1 factor, JunD. J Biol Chem 2005, 280:4785-4791.

28. Naujoks C, Meyer U, Wiesmann HP, Jasche-Meyer J, Hohoff A, Depprich R, Handschel J: Principles of cartilage tissue engineering in TMJ reconstruction. Head Face Med 2008, 4:3.

29. Hall BK, Miyake T: All for one and one for all: condensations and the initiation of skeletal development. Bioessays 2000, 22:138-147.

30. Rando TA: Stem cells, ageing and the quest for immortality. Nature 2006, 441:1080-1086.

31. Gerber I, ap Gwynn I: Influence of cell isolation, cell culture density, and cell nutrition on differentiation of rat calvarial osteoblast-like cells in vitro. Eur Cell Mater 2001, 2:10-20.

32. Depprich R, Handschel J, Wiesmann HP, Jasche-Meyer J, Meyer U: Use of bioreactors in maxillofacial tissue engineering. Br J Oral Maxillofac Surg 2008, 46:349-354.

33. Atchley WR, Hall BK: A model for development and evolution of complex morphological structures. Biol Rev Camb Philos Soc 1991, 66:101-157.

34. Hall BK, Miyake T: The membranous skeleton: the role of cell condensations in vertebrate skeletogenesis. Anat Embryol (Berl) 1992, 186:107-124.

35. Burt RK, Verda L, Kim DA, Oyama Y, Luo K, Link C: Embryonic stem cells as an alternate marrow donor source: engraftment without graft-versushost disease. J Exp Med 2004, 199:895-904.

36. Zavazava N: Embryonic stem cells and potency to induce transplantation tolerance. Expert Opin Biol Ther 2003, 3:5-13.

37. Heng BC, Cao T, Stanton LW, Robson P, Olsen B: Strategies for directing the differentiation of stem cells into the osteogenic lineage in vitro. $J$ Bone Miner Res 2004, 19:1379-1394.
38. Trounson A: Human embryonic stem cells: mother of all cell and tissue types. Reprod Biomed Online 2002, 4(Suppl 1):58-63.

39. Zhang SC, Wernig M, Duncan ID, Brustle O, Thomson JA: In vitro differentiation of transplantable neural precursors from human embryonic stem cells. Nat Biotechnol 2001, 19:1129-1133.

doi:10.1186/1746-160X-7-12

Cite this article as: Handschel et al: Embryonic stem cells in scaffoldfree three-dimensional cell culture: osteogenic differentiation and bone generation. Head \& Face Medicine 2011 7:12.

\section{Submit your next manuscript to BioMed Central and take full advantage of:}

- Convenient online submission

- Thorough peer review

- No space constraints or color figure charges

- Immediate publication on acceptance

- Inclusion in PubMed, CAS, Scopus and Google Scholar

- Research which is freely available for redistribution

Submit your manuscript at www.biomedcentral.com/submit
Biomed Central 